\title{
What can HPA axis-linked genes tell us about anxiety disorders in adolescents?
}

\author{
O que os genes associados ao eixo HPA podem nos dizer sobre os transtornos \\ de ansiedade em adolescentes?
}

\begin{abstract}
Andressa Bortoluzzi, ${ }^{1}$ Carolina Blaya, ${ }^{2}$ Eduarda Dias da Rosa, ${ }^{3}$ Mariana Paim, ${ }^{2}$ Virgínia Rosa, ${ }^{2}$ Sandra Leistner-Segal, ${ }^{4}$ Gisele Gus Manfro ${ }^{1}$
\end{abstract}

\begin{abstract}
Introduction: Anxiety disorders ( $A D)$ share features of both anxiety and fear linked to stress response. The hypothalamic- pituitary-adrenal (HPA) axis is considered the core biological pathway of the stress system and it is known that an inappropriate response to environmental stimuli may be related to individual genetic vulnerability in HPA-linked genes. Despite the biological plausibility of a relationship between the HPA axis and AD, few studies have investigated associations between genetic polymorphisms linked to the HPA axis and this complex disorder.

Objective: To investigate whether AD are associated with genetic polymorphisms in HPA-linked genes in adolescents.

Methods: Our study consisted of a cross-sectional evaluation of a community sample comprising a total of 228 adolescents (131 cases of AD). We extracted DNA from saliva and genotyped polymorphisms in HPA-linked genes (FKBP5: rs3800373, rs9296158, rs1360780, rs9470080 and rs4713916; NR3C1: rs6198; CRHR1: rs878886; and SERPINA6: rs746530) with real time polymerase chain reaction (PCR). The instruments used to diagnose and assess the severity of AD were the Schedule for Affective Disorder and Schizophrenia for School-Age Children - Present and Lifetime (K-SADS-PL) and the Screen for Child and Anxiety related Emotional Disorders (SCARED).

Results: We failed to detect any associations between $A D$ and genetic polymorphisms in HPA-linked genes ( $p>0.05)$.

Conclusion: To our knowledge, this is the first study evaluating these specific polymorphisms in relation to $A D$ in adolescents, which encourages us to design further research on the subject. Keywords: HPA axis, genetic polymorphisms, anxiety disorder, adolescents.
\end{abstract}

\section{Resumo}

Introdução: Os transtornos de ansiedade (TA) compartilham características tanto de ansiedade quanto de medo, ambos associados à resposta ao estresse. O eixo hipotálamo-pituitária-adrenal (HPA) é considerado a principal via biológica do sistema do estresse, e sabe-se que respostas inadequadas aos estímulos ambientais podem estar relacionadas à vulnerabilidade genética individual em genes do eixo HPA. Apesar da plausibilidade biológica de uma relação entre o eixo HPA e os TA, poucos estudos avaliaram a associação entre os polimorfismos genéticos de genes do eixo HPA e esse transtorno psiquiátrico complexo.

Objetivo: Investigar, em adolescentes, se os TA estão associados com polimorfismos em genes do eixo HPA.

Métodos: Nosso estudo é uma avaliação transversal realizada em uma amostra comunitária de 228 adolescentes (131 casos de TA). Foi extraído DNA de saliva e foram genotipados os polimorfismos do eixo HPA (FKBP5: rs3800373, rs9296158, rs1360780, rs9470080 e rs4713916; NR3C1: rs6198; CRHR1: rs878886; e SERPINA6: rs746530), por reação em cadeia da polimerase (PCR) em tempo real. O diagnóstico e a gravidade dos TA foram avaliados pelo instrumentos The Schedule for Affective Disorder and Schizophrenia for School-Age Children - Present and Lifetime (K-SADS-PL) e Screen for Child and Anxiety related Emotional Disorders (SCARED).

Resultados: Não foram encontradas associações entre os TA e os polimorfismos genéticos do eixo HPA $(p>0.05)$.

Conclusão: Segundo nosso conhecimento, este é o primeiro estudo que avaliou, em adolescentes, esses polimorfismos genéticos específicos do eixo HPA e sua relação com os TA, o que nos encoraja a delinear novas pesquisas sobre o assunto.

Descritores: Eixo HPA; polimorfismos genéticos; transtorno de ansiedade; adolescentes.

\footnotetext{
${ }^{1}$ Graduate Program in Neurociences, Universidade Federal do Rio Grande do Sul (UFRGS), Porto Alegre, RS, Brazil. Basic Research and Advanced Investigations in Neurosciences (BRAIN Laboratory), Hospital de Clínicas de Porto Alegre (HCPA), Porto Alegre, RS, Brazil. ${ }^{2}$ Hospital Materno-infantil Presidente Vargas, Universidade Federal de Ciências da Saúde de Porto Alegre (UFCSPA), Porto Alegre, RS, Brazil. ${ }^{3}$ BRAIN Laboratory, Hospital de Clínicas de Porto Alegre (HCPA), Porto Alegre, RS, Brazil. ${ }^{4}$ Medical Genetics Service, HCPA, Porto Alegre, RS, Brazil.

Submitted Jun 07 2015, accepted for publication Jul 31 2015. No conflicts of interest declared concerning the publication of this article.

Suggested citation: Bortoluzzi A, Blaya C, da Rosa ED, Paim M, Rosa V, Leistner-Segal S, et al. What can HPA axis-linked genes tell us about anxiety disorders in adolescents? Trends Psychiatry Psychother. 2015;37(4):232-237. http://dx.doi.org/10.1590/2237-6089-2015-0035
} 


\section{Introduction}

Anxiety disorders (AD) are associated with negative family, affective, social and economic impacts on several levels. ${ }^{1}$ Most adults with $A D$ report that their anxious symptoms had onset early in life, especially during childhood and adolescence. ${ }^{2,3}$ According to epidemiological data from multiple sources, the prevalence of $A D$ ranges from 3.1 to $17.5 \%$ in children and adolescents, ${ }^{4}$ while the current global prevalence is $7.3 \% .^{5}$ It is accepted that $A D$ are complex disorders linked to multiple genes ${ }^{6}$ and several different environmental vulnerabilities. ${ }^{7-9}$

The hypothalamic-pituitary-adrenal (HPA) axis is the central component of the stress system and is responsible for people's reactivity to stress. ${ }^{10,11}$ This axis mediates the association between early life stress and development of mood disorders in adulthood. ${ }^{12-16}$ Studies with animal models have described a number of mechanisms underlying the stress-induced neuronal plasticity leading to fear and anxiety, ${ }^{17}$ but very few studies in humans have been published.

One animal study ${ }^{18}$ investigated the consequences of imbalance between mRNA levels of the mineralocorticoid receptor (MR) and the glucocorticoid receptor (GR), which are involved with regulation of the HPA axis, ${ }^{19}$ suggesting that there is significant interaction between these receptors and control of the HPA-axis under stress. This result further intensified the focus on mechanisms involving the HPA axis in behavior.

Serine protease inhibitors (SERPINA) are a family of proteins that includes the corticosteroid-binding globulin (CBG), which is involved in transport of glucocorticoids. Corticosteroid-binding globulin has the ability to bind 80 $90 \%$ of cortisol in plasma. ${ }^{20}$

The NR3C1 gene encodes a GR and has been associated with modification of physiological stress response and mood disorders, ${ }^{21}$ but not in all studies. ${ }^{22}$ The FKBP5 gene, a co-chaperone of hsp90, is responsible for regulation of GR sensitivity to cortisol. Overexpression of FKBP5 would be expected to result in an attenuation of the negative feedback inhibition. ${ }^{23}$ Alleles associated with enhanced expression of FKBP5 following GR activation lead to increased GR resistance and decreased HPA axis efficiency in healthy controls. This result prolongs activation of the stress hormone system following exposure to stress. ${ }^{24}$ Accordingly, genetic polymorphisms of FKBP5 gene have been associated with recurrence of depressive episodes and with incomplete normalization of stress-elicited cortisol secretion and, in interaction with childhood trauma, predict post-traumatic stress disorder (PTSD), aggressive behavior and suicidal behavior, ${ }^{25-28}$ and are also linked with increased self-reported anxiety after psychosocial stress. ${ }^{29}$
Genetic variations in the gene for corticotropin releasing hormone $(\mathrm{CRH})$ are associated with behavioral inhibition in children, which is a temperament that has been related to development of $A D$ in adulthood. ${ }^{30}$ Corticotropin-releasing hormone receptor 1 subtype (CRHR1) is involved in the anxiogenic action of $\mathrm{CRH} .{ }^{31}$ Animal models have shown that mice lacking a functional CRHR1 exhibited less anxious behavior in comparison with wild mice. ${ }^{32}$ Therefore, our primary objective is to explore, in a sample of adolescents, the role that polymorphisms in candidate HPA-linked genes play in $A D$ and anxiety symptoms. Our hypothesis is that these genetic variants might be associated with early-onset $A D$ in an adolescent sample.

\section{Methods}

\section{Sample selection and psychiatric evaluation}

Adolescents were selected from a larger community sample enrolled at schools within the area served by the Hospital de Clínicas de Porto Alegre (HCPA), Brazil. The sampling procedures have been described in detail elsewhere. ${ }^{33}$ The ethical and methodological aspects of this study were approved and all participants provided informed consent in writing.

All subjects who were rated above the 75th percentile in the Screen for Child and Anxiety related Emotional Disorders (SCARED) ${ }^{34}$ and a random sample of the other 3 quartiles were invited to attend a clinical interview and were also assessed using the Brazilian version of the Schedule for Affective Disorder and Schizophrenia for School-Age Children - Present and Lifetime (K-SADS$\mathrm{PL}),{ }^{35,36}$ which is a semi-structured interview based on Diagnostic and Statistical Manual of Mental Disorders, fourth edition (DSM-IV) criteria.

Adolescents who were diagnosed with social anxiety disorder, generalized anxiety disorder, separation anxiety disorder or panic disorder according to the K-SADS-PL were classified as cases. Subjects with no $A D$ other than specific phobias were classified as controls. Anxiety severity symptoms were measured using SCARED results expressed as means and standard deviations.

We excluded from this study people who had: 1) significant organic illness; 2) history of bipolar disorder, pervasive developmental disorder or any psychotic disorder; 3) history of alcohol or drug dependency or abuse; 4) clinical suspicion of intellectual disability and 5) subjects whose genotype was not clearly defined. 


\section{Participants}

The initial sample comprised 240 adolescents who agreed to participate in the psychiatric diagnostic assessment and provided biological material (saliva) for DNA studies. Only unrelated individuals were included ( $n=234)$. Six subjects were excluded because of intellectual disability ( 3 controls and 3 cases). The final sample comprised 228 adolescents $(67.98 \%$ females; mean age $=12.81 \pm 2.39): 131$ cases $(74 \%$ females; mean age $=13.1 \pm 2.36 ; 65.9 \%$ Caucasians) and 97 controls $(59.8 \%$ females; mean age $=12.54 \pm 2.41$; 73.4\% Caucasians). Ethnicity was determined by selfreport on the basis of skin color. Our entire adolescent sample comprised 152 Caucasians, 30 African-Brazilians and 38 mixed individuals with skin color between white and black. Data on ethnicity were missing for 8 participants. There was no difference in ethnicity distribution between cases and controls.

There were a total of 131 cases, $93(71 \%)$ of whom were diagnosed with generalized anxiety disorder, 55 $(42 \%)$ with social anxiety disorder, 46 (35.1\%) with separation anxiety disorder and 9 (6.9\%) with panic disorder. Of these, 75 (57.3\%) had one AD only, 41 $(31.3 \%)$ had two $A D$ and $15(1.5 \%)$ had three or four $A D$, as has been observed elsewhere. ${ }^{37}$

\section{Selection of polymorphisms of candidate genes}

We selected single nucleotide polymorphisms (SNPs) on the basis of the results of searches performed on the MEDLINE, Cochrane and PubMed databases for studies involving dysregulation of the HPA axis. Candidate genes were chosen on the basis of their roles in psychiatric disorders, according to the literature. We found 17 SNPS of candidate HPA linked-genes: FKBP5 (rs3800373, rs9296158, rs1360780, rs9470080, rs4713916); AVPR1B (rs28632197, rs28529127, rs28575468, rs33933482); NR3C1 (rs6198, rs6189); SERPINA6 (rs746530); NR3C2 (rs2070951, rs5522); CRH (rs6159, rs6999100) and CRHR1 (rs878886). Five of these SNPs (rs6189, rs4713916, rs5522, rs6159, rs69999100) were excluded because their minor allele counts (MAF) were below $5 \%$. Our final selection comprised 8 SNPs of candidate genes: FKBP5 (rs3800373, rs9296158, rs1360780, rs9470080 and rs4713916); NR3C1 (rs6198); CRHR1 (rs878886) and SERPINA6 (rs746530).

\section{Genotyping}

DNA was extracted from biological samples of saliva using an Oragene ${ }^{\mathrm{TM}}$ Kit. All SNPs were detected using real-time polymerase chain reaction (PCR). All of the conditions of the genotyping process have been described in detail elsewhere. ${ }^{38}$

\section{Statistical analyses}

Analyses of associations and the test of Hardy-Weinberg Equilibrium (HWE) were performed using PLINK software. ${ }^{39}$ The overall level of significance adopted was $a=0.05$. Descriptive data were obtained using SPSS version 18 and expressed as means, standard deviations, and n (\%).

We performed single marker association tests and we adjusted the p-values to incorporate correction for multiple hypothesis testing with permutations ( $\mathrm{n}=$ 10,000 permutations) corrected for both gene-wise $\left(p^{1}\right)$ and experiment-wise $\left(\mathrm{p}^{2}\right)$ significance values.

\section{Results}

Our total sample was in HWE. Table 1 lists descriptive statistics for the test of HWE, the casecontrol association study (K-SADS-PL analysis) and the severity of anxiety symptoms according to SCARED. The tests of allelic associations detected no differences between $A D$ cases and controls in the frequencies of our selection of SNPs.

\section{Discussion}

Contrary to our hypothesis, we did not find any associations between a selection of genetic variants (FKBP5: rs3800373, rs9296158, rs1360780, rs94700870, rs4713916; NR3C1: rs6198; CRHR1: rs878886 and SERPINA6: rs746530) and $A D$ in our adolescent sample.

The high proportion of psychiatric comorbidities in our sample may have contributed to the absence of evidence of associations between HPA-linked genes and AD. Since our sample is comprised of people from the community, it is possible that adolescents who had externalizing disorder comorbidities could have attended the psychiatric evaluation more frequently.

We observed that there is a paucity of studies investigating genetic variants of the FKBP5 gene in connection with $A D,{ }^{40}$ although some studies have investigated this gene with relation to other psychiatric disorders such as bipolar disorder and depression and environmental interactions with it in relation to risk of PTSD. ${ }^{28,41,42}$ Therefore, in an attempt to infer some hypotheses concerning $A D$, our discussions will be partially based on these other psychiatric disorders. 
Table 1 - Allelic association between SNPs of HPA-linked genes and K-SADS-PL and SCARED scores $(n=228)$ in a case-control study of anxiety disorders

\begin{tabular}{|c|c|c|c|c|c|c|c|c|c|c|c|c|}
\hline \multicolumn{8}{|c|}{ K-SADS-PL $(n=228)$} & \multicolumn{5}{|c|}{ SCARED $(n=228)$} \\
\hline Gene & SNP & MA & FA & FU & $x^{2}$ & OR (95\%CI) & $\mathbf{p}$ & P HWE & $\boldsymbol{\beta}$ & $r^{2}$ & $\mathbf{T}$ & $\underset{\text { permuted }}{p}$ \\
\hline NR3C1 & rs6198 & C & 0.09 & 0.09 & 0.004 & $\begin{array}{c}0.98 \\
(0.51-1.86)\end{array}$ & 0.951 & 0.702 & -0.895 & 0.0008 & -0.433 & 0.666 \\
\hline \multirow[t]{5}{*}{ FKBP5 } & rs3800373 & C & 0.33 & 0.30 & 0.4386 & $\begin{array}{c}1.15 \\
(0.76-1.72)\end{array}$ & 0.508 & 0.17 & 0.125 & $\begin{array}{c}4.765 \mathrm{e}- \\
005\end{array}$ & 0.103 & 0.918 \\
\hline & rs9296158 & $A$ & 0.38 & 0.35 & 0.414 & $\begin{array}{c}1.14 \\
(0.77-1.68)\end{array}$ & 0.520 & 0.253 & 0.658 & 0.001 & 0.563 & 0.574 \\
\hline & rs1360780 & $\mathrm{T}$ & 0.34 & 0.31 & 0.5865 & $\begin{array}{c}1.17 \\
(0.78-1.74)\end{array}$ & 0.444 & 0.178 & 0.128 & $\begin{array}{c}5.098 \mathrm{e}- \\
005\end{array}$ & 0.107 & 0.915 \\
\hline & rs9470080 & $\mathrm{T}$ & 0.38 & 0.35 & 0.3483 & $\begin{array}{c}1.12 \\
(0.76-1.66)\end{array}$ & 0.555 & 0.318 & 0.575 & 0.001 & 0.489 & 0.625 \\
\hline & rs4713916 & $A$ & 0.23 & 0.25 & 0.1193 & $\begin{array}{c}0.93 \\
(0.60-1.43)\end{array}$ & 0.730 & 0.858 & -1.923 & 0.009 & -1.431 & 0.154 \\
\hline SERPINA6 & rs746530 & $A$ & 0.37 & 0.44 & 2.231 & $\begin{array}{c}0.75 \\
(0.51-1.09)\end{array}$ & 0.135 & 0.489 & -2.155 & 0.014 & -1.766 & 0.079 \\
\hline CRHR1 & rs878886 & G & 0.13 & 0.19 & 2.621 & $\begin{array}{c}0.65 \\
(0.39-1.09)\end{array}$ & 0.105 & 0.465 & -0.973 & 0.002 & -0.610 & 0.543 \\
\hline
\end{tabular}

$95 \% \mathrm{CI}=95 \%$ confidence interval; $\beta=$ regression coefficient; $r^{2}=$ regression $r$-squared; $x^{2}=$ chi-square test; CRHR1 = corticotropin releasing hormone receptor 1 ; FKBP5 = FK506 binding protein 5; FA = frequency of risk allele in cases; FU = frequency of risk allele in controls; HPA = hypothalamic-pituitary-adrenal; HWE = Hardy-Weinberg equilibrium; K-SADS-PL = The Schedule for Affective Disorder and Schizophrenia for School-Age Children - Present and Lifetime; MA = minor allele; NR3C1 = nuclear receptor subfamily 3, group C, member 1 (glucocorticoid receptor); NR3C2 = nuclear receptor subfamily 3, group C, member 2 (mineralocorticoid receptor); OR = odds ratio; $\mathrm{p}=$ Wald-test asymptotic $\mathrm{p}$-value; SCARED = Screen for Child and Anxiety related Emotional Disorders; SERPINA6 $=$ serpin peptidase inhibitor, clade A (alpha-1 antiproteinase, antitrypsin), member 6; SNP = single nucleotide polymorphism; $\mathrm{T}=$ Wald test (based on $\mathrm{t}$ distribution).

Minelli et al. ${ }^{40}$ showed that homozygosis for the $\mathrm{T}$ allele of rs 1360780 is significantly more frequent in patients affected by major depression with co-morbid $A D$ than in those without co-morbid AD. A study with young adults indicated faster cortisol recovery after acute stress in individuals with the CC genotype who had been exposed to maltreatment during childhood, whereas no association was observed among $T$ allele carriers. $^{43}$ The $T$ allele and $T$ genotype of rs1360780 were overrepresented in individuals with depression ${ }^{28,44}$ and also had a strong trend for association with bipolar disorder in a large family-based sample. ${ }^{41}$ Additionally, the $\Pi$ genotype of rs1360780 exhibited incongruent results in relation to faster response to antidepressant treatment with studies observing both associations ${ }^{28}$ and absence of associations ${ }^{45}$ to this polymorphism. The FKBP5 polymorphisms (rs4713916, rs3800373 and rs1360780) were also investigated in a sample of affective psychosis cases (depression and bipolar disorder) and controls, but without any associations. ${ }^{46}$ Moreover, all five of the FKBP5 gene SNPs that we studied were also evaluated in a recent study that suggested an association in depression patients but not with bipolar disorders. ${ }^{47}$ These results illustrate the challenge of finding associations involving candidate genes and complex disorders.

The NR3C1 gene (GR) has previously been linked to depression and bipolar disorder. ${ }^{21,48}$ The interaction between rs6198 of the NR3C1 gene and rs9470080 of the FKBP5 gene may modulate the risk for depression by contributing to inhibition of GR signaling, ${ }^{47}$ although no association between this polymorphism and melancholic features in the course of bipolar disorder was found in another study. ${ }^{22}$ We also did not find associations between these polymorphism and AD.

Our study also involved the rs878886 polymorphism of the CRHR1 gene. In two German samples ${ }^{49}$ rs878886 was highly associated with panic disorders, but was not associated with depression in the course of bipolar disorder.22 Among young adults, G-allele carriers showed no acquisition of fear conditioned responses to the threat cue in the uninstructed phase, whereas fear acquisition was present in people homozygous for the $\mathrm{C}$ allele. ${ }^{50}$ Fear acquisition deficit is relevant in the pathogenesis of human AD. ${ }^{51}$

Finally, we evaluated the rs746530 polymorphism of the SERPINA6 gene in AD. We found only one study describing associations between this specific SNP and multiple somatic symptoms (including symptoms of anxiety). ${ }^{52}$

Our study has two main limitations. First, our sample size was small and this may have limited our power to detect associations with modest to moderate effect sizes. Second, we did not test HPA axis function by assaying cortisol levels under stress stimuli.

Our study provides additional data about some polymorphisms of HPA-linked genes in AD. Although these HPA-specific SNPs are biologically plausible; there is a paucity of literature concerning their relationships with development of psychiatric disorders. Another important feature of this study was the use of a sample of adolescents. Adolescence is a critical period for development of anxiety and affective 
disorders in response to stress. ${ }^{53}$ We believe that these data should encourage future studies investigating the stress axis and functional polymorphisms, taking environmental interactions and epigenetic influences into consideration.

\section{Conclusion}

We used a strict methodology to select functional polymorphisms of HPA-linked genes and did not find any associations between these genetic variants and $A D$ in adolescents. We suggest that further studies involving these genes should be designed and conducted using larger adolescent samples, in order to improve our understanding of possible HPA axis mechanisms in AD during this important developmental period.

\section{References}

1. Salum GA, DeSousa DA, do Rosário MC, Pine DS, Manfro GG. Pediatric anxiety disorders: from neuroscience to evidence-based clinical practice. Rev Bras Psiquiatr. 2013;35:S03-21.

2. Beesdo K, Knappe S, Pine DS. Anxiety and anxiety disorders in children and adolescents: developmental issues and implications for DSM-V. Psychiatr Clin North Am. 2009;32:483-524.

3. Beesdo-Baum K, Knappe S, Fehm L, Höfler M, Lieb R, Hofmann SG, et al. The natural course of social anxiety disorder among adolescents and young adults. Acta Psychiatr Scand. 2012;126:411-25.

4. Rockhill C, Kodish I, DiBattisto C, Macias M, Varley C, Ryan S. Anxiety disorders in children and adolescents. Curr Probl Pediatr Adolesc Health Care. 2010;40:66-99.

5. Baxter AJ, Scott KM, Vos T, Whiteford HA. Global prevalence of anxiety disorders: a systematic review and meta-regression. Psychol Med. 2013;43:897-910.

6. Hettema JM1, Neale MC, Kendler KS. A review and meta-analysis of the genetic epidemiology of anxiety disorders. Am J Psychiatry. 2001;158:1568-78.

7. Klengel T, Mehta D, Anacker C, Rex-Haffner M, Pruessner JC, Pariante CM, et al. Allele-specific FKBP5 DNA demethylation mediates gene-childhood trauma interactions. Nat Neurosci. 2013;16:33-41.

8. Laucht $M$, Treutlein J, Blomeyer $D$, Buchmann AF, Schmid B, Becker $K$, et al. Interaction between the 5-HTTLPR serotonin transporter polymorphism and environmental adversity for mood and anxiety psychopathology: evidence from a high-risk community sample of young adults. Int J Neuropsychopharmacol. 2009;12:737-47.

9. Petersen IT, Bates JE, Goodnight JA, Dodge KA, Lansford JE, Pettit $\mathrm{GS}$, et al. Interaction between serotonin transporter polymorphism (5-HTTLPR) and stressful life events in adolescents' trajectories of anxious/depressed symptoms. Dev Psychol. 2012;48:1463-75.

10. de Kloet ER, Joëls $M$, Holsboer F. Stress and the brain: from adaptation to disease. Nat Rev Neurosci. 2005;6:463-75.

11. Derijk RH. Single nucleotide polymorphisms related to HPA axis reactivity. Neuroimmunomodulation. 2009;16:340-52.

12. Baes Cv, Martins CM, Tofoli SM, Juruena MF. Early life stress in depressive patients: HPA Axis response to GR and MR agonist. Front Psychiatry. 2014;5:2.

13. Heim C, Newport DJ, Heit S, Graham YP, Wilcox M, Bonsall R, et al. Pituitary-adrenal and autonomic responses to stress in women after sexual and physical abuse in childhood. JAMA. 2000;284:592-7.

14. Heim C, Newport DJ, Mletzko T, Miller AH, Nemeroff CB. The link between childhood trauma and depression: insights from HPA axis studies in humans. Psychoneuroendocrinology. 2008;33:693-710.

15. Dempster EL, Burcescu I, Wigg K, Kiss E, Baji I, Gadoros J, et al. Further genetic evidence implicates the vasopressin system in childhood-onset mood disorders. Eur J Neurosci. 2009;30:1615-9.

16. Shea A, Walsh $C$, Macmillan $H$, Steiner $M$. Child maltreatment and HPA axis dysregulation: relationship to major depressive disorder and post traumatic stress disorder in females. Psychoneuroendocrinology. 2005;30:162-78.

17. Pawlak R, Magarinos AM, Melchor J, McEwen B, Strickland S. Tissue plasminogen activator in the amygdala is critical for stressinduced anxiety-like behavior. Nat Neurosci. 2003;6:168-74.

18. Harris a P, Holmes MC, de Kloet ER, Chapman KE, Seckl JR. Mineralocorticoid and glucocorticoid receptor balance in control of HPA axis and behaviour. Psychoneuroendocrinology. 2013;38:648-58.

19. Derijk RH, de Kloet ER. Corticosteroid receptor polymorphisms: determinants of vulnerability and resilience. Eur J Pharmacol. 2008;583:303-11.

20. Irving JA, Pike RN, Lesk AM, Whisstock JC. Phylogeny of the serpin superfamily: implications of patterns of amino acid conservation for structure and function. Genome Res. 2000;10:1845-64.

21. Szczepankiewicz A, Leszczyńska-Rodziewicz A, Pawlak J, Rajewska-Rager A, Dmitrzak-Weglarz $M$, Wilkosc $M$, et al. Glucocorticoid receptor polymorphism is associated with major depression and predominance of depression in the course of bipolar disorder. J Affect Disord. 2011;134:138-44.

22. Leszczyńska-Rodziewicz A, Szczepankiewicz A, Dmitrzak-Węglarz M, Rajewska-Rager A, Skibińska M, Hauser J. No association between polymorphisms and haplotypes of the AVPR1b, CRHR1 and NR3C1 genes and depression with melancholic features in the course of bipolar disorder. Psychiatry Res. 2013;207:140-2.

23. Denny WB, Valentine DL, Reynolds PD, Smith DF, Scammell JG. Squirrel monkey immunophilin FKBP51 Is a potent inhibitor of glucocorticoid receptor binding. Endocrinology. 2000;141:4107-13.

24. Binder EB. The role of FKBP5, a co-chaperone of the glucocorticoid receptor in the pathogenesis and therapy of affective and anxiety disorders. Psychoneuroendocrinology. 2009;34:S186-95.

25. Roy A, Gorodetsky E, Yuan Q, Goldman D, Enoch MA. Interaction of FKBP5, a stress-related gene, with childhood trauma increases the risk for attempting suicide. Neuropsychopharmacology. 2010;35:1674-83.

26. Bevilacqua L, Carli V, Sarchiapone M, George DK, Goldman D, Roy $A$, et al. Interaction between FKBP5 and childhood trauma and risk of aggressive behavior. Arch Gen Psychiatry. 2012;69:62-70.

27. Zimmermann $P$, Bruckl $T$, Nocon $A$, Pfister $H$, Binder EB, Uhr $M$, et al. Interaction of FKBP5 gene variants and adverse life events in predicting depression onset: results from a 10-year prospective community study. Am J Psychiatry. 2011;168:1107-16.

28. Binder EB, Salyakina D, Lichtner $P$, Wochnik GM, Ising $M$, Pütz $B$, et al. Polymorphisms in FKBP5 are associated with increased recurrence of depressive episodes and rapid response to antidepressant treatment. Nat Genet. 2004;36:1319-25.

29. Ising M, Depping AM, Siebertz A, Lucae S, Unschuld PG, Kloiber $S$, et al. Polymorphisms in the FKBP5 gene region modulate recovery from psychosocial stress in healthy controls. Eur J Neurosci. 2008;28:389-98.

30. Smoller JW, Rosenbaum JF, Biederman J, Kennedy J, Dai $D$, Racette $S R$, et al. Association of a genetic marker at the corticotropin-releasing hormone locus with behavioral inhibition. Biol Psychiatry. 2003;54:1376-81.

31. Müller MB, Wurst W. Getting closer to affective disorders: the role of CRH receptor systems. Trends Mol Med. 2004;10:409-15.

32. Timpl P, Spanagel R, Sillaber I, Kresse A, Reul JM, Stalla GK, et al. Impaired stress response and reduced anxiety in mice lacking a functional corticotropin-releasing hormone receptor 1 . Nat Genet. 1998;19:162-6.

33. Salum GA, Isolan LR, Bosa VL, Tocchetto AG, Teche SP, Schuch I, et al. The multidimensional evaluation and treatment of anxiety in children and adolescents: rationale, design, methods and preliminary findings. Rev Bras Psiquiatr. 2011;33:181-95.

34. Isolan L, Salum GA, Osowski AT, Amaro E, Manfro GG. Psychometric properties of the Screen for Child Anxiety Related Emotional Disorders (SCARED) in Brazilian children and adolescents. J Anxiety Disord. 2011;25:741-8.

35. Kaufman J, Birmaher B, Brent D, Rao U, Flynn C, Moreci $P$, et al. Schedule for Affective Disorders and Schizophrenia for SchoolAged Children-Present and Lifetime Version (K-SADS-PL): initial reliability and validity data. J Am Acad Child Adolesc Psychiatry. 1997;36:980-8.

36. Polanczyk G V, Eizirik M, Aranovich V, Denardin D, da Silva TL, da Conceição TV, et al. Interrater agreement for the schedule 
for affective disorders and schizophrenia epidemiological version for school-age children (K-SADS-E). Rev Bras Psiquiatr. 2003;25:87-90.

37. Tocchetto A, Salum GA, Blaya C, Teche S, Isolan L, Bortoluzzi A, et al. Evidence of association between Val66Met polymorphism at BDNF gene and anxiety disorders in a community sample of children and adolescents. Neurosci Lett. 2011;502:197-200.

38. Bortoluzzi A, Salum GA, Blaya C, Silveira PP, Grassi-Oliveira R, da Rosa ED, et al. Mineralocorticoid receptor genotype moderates the association between physical neglect and serum BDNF. J Psychiatr Res. 2014;59:8-13.

39. Purcell S, Neale B, Todd-Brown K, Thomas L, Ferreira MA Bender D, et al. PLINK: a tool set for whole-genome association and population-based linkage analyses. Am J Hum Genet. 2007;81:559-75.

40. Minelli A, Maffioletti E, Cloninger CR, Magri C, Sartori R, Bortolomasi $M$, et al. Role of allelic variants of FK506-binding protein 51 (FKBP5) gene in the development of anxiety disorders. Depress Anxiety. 2013;30:1170-6.

41. Willour VL, Chen H, Toolan J, Belmonte P, Cutler DJ, Goes FS, et al. Family-based association of FKBP5 in bipolar disorder. Mol Psychiatry. 2009;14:261-8.

42. Xie P, Kranzler HR, Poling J, Stein MB, Anton RF, Farrer LA, et al. Interaction of FKBP5 with childhood adversity on risk for post-traumatic stress disorder. Neuropsychopharmacology. 2010;35:1684-92.

43. Buchmann AF, Holz N, Boecker R, Blomeyer D, Rietschel M, Witt $\mathrm{SH}$, et al. Moderating role of FKBP5 genotype in the impact of childhood adversity on cortisol stress response during adulthood. Eur Neuropsychopharmacol. 2014;24:837-45.

44. Lavebratt C, Aberg E, Sjöholm LK, Forsell Y. Variations in FKBP5 and BDNF genes are suggestively associated with depression in a Swedish population-based cohort. J Affect Disord. 2010;125:249-55.

45. Tsai SJ, Hong CJ, Chen TJ, Yu YW. Lack of supporting evidence for a genetic association of the FKBP5 polymorphism and response to antidepressant treatment. Am J Med Genet B Neuropsychiatr Genet. 2007;144B:1097-8.
46. Gawlik M, Moller-Ehrlich K, Mende M, Jovnerovski M, Jung S, Jabs $B$, et al. Is FKBP5 a genetic marker of affective psychosis? A case control study and analysis of disease related traits. BMC Psychiatry. 2006;6:52.

47. Szczepankiewicz A, Leszczyńska-Rodziewicz A, Pawlak J, Narozna $B$, Rajewska-Rager A, Wilkosc $M$, et al. FKBP5 polymorphism is associated with major depression but not with bipolar disorder. J Affect Disord. 2014;164:33-7.

48. Spijker AT, Giltay EJ, van Rossum EF, Manenschijn L, DeRijk RH, Haffmans J, et al. Glucocorticoid and mineralocorticoid receptor polymorphisms and clinical characteristics in bipolar disorder patients. Psychoneuroendocrinology. 2011;36:1460-9.

49. Keck ME, Kern N, Erhardt A, Unschuld PG, Ising M, Salyakina D, et al. Combined effects of exonic polymorphisms in CRHR1 and AVPR1B genes in a case/control study for panic disorder. Am J Med Genet B Neuropsychiatr Genet. 2008;147B:1196-204.

50. Heitland I, Groenink L, Bijlsma EY, Oosting RS, Baas JM. Human fear acquisition deficits in relation to genetic variants of the corticotropin releasing hormone receptor 1 and the serotonin transporter. PLoS One. 2013;8:e63772.

51. Waters AM, Peters RM, Forrest KE, Zimmer-Gembeck M. Fear acquisition and extinction in offspring of mothers with anxiety and depressive disorders. Dev Cogn Neurosci. 2014;7:30-42.

52. Holliday KL, Macfarlane GJ, Nicholl BI, Creed F, Thomson W, McBeth J. Genetic variation in neuroendocrine genes associates with somatic symptoms in the general population: results from the EPIFUND study. J Psychosom Res. 2010;68:469-74.

53. Eiland $\mathrm{L}$, Romeo RD. Stress and the developing adolescent brain. Neuroscience. 2013;249:162-71.

\section{Correspondence:}

Andressa Bortoluzzi

Hospital de clínicas de Porto alegre (HCPA)

Rua Ramiro Barcelos, 2350, BRAIN Laboratory

90035-003 - Porto Alegre, RS - Brazil

E-mail: andresbt10@yahoo.com.br 